UDC 577.217.535+ 577.322.23

\title{
Protein partners of the eEF1B $\beta$ subunit of the translation elongation complex eEF1B in the nuclear fraction of human lung carcinoma cells
}

\author{
L. M. Kapustian ${ }^{1}$, M. Dadlez ${ }^{2}$, B. S. Negrutskii ${ }^{1}$ \\ ${ }^{1}$ Institute of Molecular Biology and Genetics, NAS of Ukraine \\ 150, Akademika Zabolotnoho Str., Kyiv, Ukraine, 03680 \\ 2 Institute of Biochemistry and Biophysics, Polish Academy of Sciences \\ 5a, Pawinskiego, Warsaw, Poland, 02-106 \\ negrutskii@imbg.org.ua
}

\begin{abstract}
Aim. To identify novel protein partners of translation factor eEF1B $\beta$ in nucleus of human lung carcinoma cells. Methods. Protein partners of eEF1B $\beta$ in the nuclear fraction of A549 cells were identified by co-immunoprecipitation (co-IP) combined with liquid chromatographytandem mass spectrometry (LC-MS/MS). Specific protein partners of eEF1B $\beta$ were further selected by using the results of previously published global, quantitative and dynamic mapping of protein subcellular localization with help of "Mapofthecell" program. Results. 104 highscored proteins interacting with eEF1B $\beta$ in the nuclear fraction of A549 cells have been identified by mass-spectrometry. Among these proteins, 9 partners of eEF1B $\beta$ were confirmed by the co-fractionation approach. Functional analysis of the partners has divided them on the pro-oncogenic (lung-cancer related) and neutral/anti-oncogenic moieties. These two groups are estimated to be spatially separated in human cancer cells. Conclusions. The position of eEF1B $\beta$ as a link between the oncogenic and neutral/tumor-suppressor moieties of its protein partners in nucleus of lung cancer cells is suggested. Deciphering of a possible role of the eEF1B $\beta$ distribution between the pro-cancer or anti-cancer communities of its protein partners can be a subject of further research.
\end{abstract}

Ke y w o r d s: eEF1B $\beta$, protein-protein interactions, A549 cells, ILF2, ILF3, HNRNPU, CELF1, DDX6, CCNT1, PA2G4, SPATS2L, USP39.

\section{Introduction}

eEF1B $\beta$ is a nucleotide-exchanging subunit of translation elongation complex eEF1B. This complex, along with eEF1A protein, play a main role in the elongation cycle of human translating ribosome providing GTP-dependent aminoacyl-tRNA recognition in the A-site $[1,2]$.

Stability of the eEF1B complex in carcinogenesis was recently questioned $[3,4]$ suggesting that its subunits including eEF1B $\beta$

(C) 2017 L. M. Kapustian et al.; Published by the Institute of Molecular Biology and Genetics, NAS of Ukraine on behalf of Biopolymers and Cell. This is an Open Access article distributed under the terms of the Creative Commons Attribution License (http://creativecommons.org/licenses/by/4.0/), which permits unrestricted reuse, distribution, and reproduction in any medium, provided the original work is properly cited 
may fulfill non-canonical functions separately from the complex. It is known that eEF1B $\beta$ participates in $\mathrm{Cd}^{2+}$-induced oncogenesis [5], eEF1B $\beta$ mRNA is overexpressed in human tumors [6]. Overexpression of eEF1B $\beta$ was reported to be associated with the chemoresistance of malignant melanoma [7]. Nuclear localization of eEF1B $\beta$ was shown $[3,4]$ which apparently contradicts to a common belief that no translation occurs in nucleus. However, nuclear eEF1B $\beta$ may play some non-canonical and possibly cancer-related roles which are not directly related to the protein synthesis.

In an attempt to identify these roles we present here a data on the experimental analysis of the eEF1B $\beta$ protein partners in the nuclear fraction of the human lung carcinoma cell line A549. A number of the proteins were found, and, what is most important, nine eEF1B $\beta$ partners identified by co-precipitation were confirmed by the co-localization data in the HeLa cells extract by the Mapofthecell program (http://www.mapofthecell.org). Importantly, these 9 proteins can be functionally divided on the pro-oncogenic and neutral/ tumor-suppressing groups separated in cellular space. These two moieties can be connected via eEF1B $\beta$ protein.

\section{Materials and Methods}

\section{Obtaining of nuclear fraction}

A549 cells were cultured in DMEM (Sigma, USA) growth medium with $10 \%$ FBS (Sigma, USA) and $1 \%$ penicillin/streptomycin (Sigma). Cells were grown up to $80 \%$ confluency and harvested with Trypsin-EDTA and phosphate buffered saline (PBS). Nuclear fraction was obtained as described in [8] with modifications. Cells were resuspended in 1 volume of lysis buffer (10 mM HEPES pH7,9; 1,5 mM $\mathrm{MgCl}_{2} ; 10 \mathrm{mM} \mathrm{KCl} ; 0,5 \%$ NP-40; 0,2 mM PMSF; 0,5 mM DTT) and incubated on ice for $20 \mathrm{~min}$. Suspended cells were centrifuged at $400 \mathrm{~g}$ for $10 \mathrm{~min}$. Precipitate was resuspended in 4.5 volumes of the buffer comprising $10 \mathrm{mM}$ HEPES, $0.25 \mathrm{mM}$ sucrose, $1.5 \mathrm{mM} \mathrm{MgCl}_{2}$, $10 \mathrm{mM} \mathrm{KCl}, 0.1 \% \mathrm{NP}-40,0.5 \mathrm{mM}$ DTT, $0.2 \mathrm{mM}$ PMSF and kept $10 \mathrm{~min}$ on ice to provide protein extraction. The suspension was loaded on sucrose cushion (2M) and centrifuged at $400 \mathrm{~g}$ for $10 \mathrm{~min}$. Nuclei were resuspended in the lysis buffer and centrifuged at $1500 \mathrm{~g}$ for $10 \mathrm{~min}$. The procedure was repeated twice. The nuclear pellet was resuspended in a half of initial cell volume of the nucleus lysis buffer (20 mM HEPES pH 7.9, $25 \%$ glycerol, $0.42 \mathrm{M} \mathrm{NaCl}, 1.5 \mathrm{mM} \mathrm{MgCl}_{2}$, $0.2 \mathrm{mM}$ DTT, $0.2 \mathrm{mM}$ EDTA, $0.2 \mathrm{mM}$ PMSF), incubated on ice for $30 \mathrm{~min}$ and centrifuged at $16000 \mathrm{~g}$ for $30 \mathrm{~min}$. The supernatant was used as a protein nuclear fraction.

\section{Co-immunoprecipitation}

Nuclear fraction of A549 cells was incubated with Protein G Sepharose (Sigma, USA) for 1 hour at $4{ }^{\circ} \mathrm{C}$ for pre-clearing. Mouse antieEF1B $\beta$ antibodies (Abnova, Taiwan) $(1.5 \mu \mathrm{g}$ of antibodies per $1 \mathrm{mg}$ of total protein) were added to pre-cleared lysates and the incubation persisted overnight at $4{ }^{\circ} \mathrm{C}$. To precipitate the antibody-protein complex, Protein G Sepharose was added according to the manufacturer's protocol and incubated for 2 hours at $4{ }^{\circ} \mathrm{C}$. The samples were analyzed by $12 \%$ PAGE. Gel was stained with the colloidal CBB-G250 [9]. To control non-specific binding the eluate of 
the nuclear fraction loaded on empty Protein G-Sepharose was used. Protein bands of interest were cut and processed for mass-spectrometry analysis (LC-MS/MS).

\section{$L C-M S / M S$}

Mass spectrometry analysis was conducted at the Mass Spectrometry Laboratory of the Institute of Biochemistry and Biophysics (Warsaw, Poland). Proteins from each band were digested with trypsin. MS analysis was performed used a LTQ-Orbitrap Velos mass spectrometer (Thermo Scientific) coupled with a nanoAcquity (Waters Corporation) LC system. Spectrometer parameters were as follows: polarity mode, positive; capillary voltage, $1.5 \mathrm{kV}$. A sample was first applied to the nanoACQUITY UPLC Trapping Column (Waters) using water containing $0.1 \%$ formic acid as the mobile phase. Next, the peptide mixture was transferred to the nanoACQUITY UPLC BEH C18 Column (Waters, $75 \mu \mathrm{m}$ inner diameter; $250 \mathrm{~mm}$ long) and an ACN gradient (5-40\% over $100 \mathrm{~min}$ ) was applied in the presence of $0.1 \%$ formic acid with a flow rate of $250 \mathrm{nl} / \mathrm{min}$ and eluted directly to the ion source of the mass spectrometer. Each LC run was preceded by a blank run to avoid sample carry-over between the analyses.

The acquired MS/MS data were pre-processed with Mascot Distiller (version 2.3.2.0, Matrix Science, London, UK). The initial search parameters were set as follows: enzyme, trypsin; variable modifications, carbamidomethyl, oxidation; peptide mass tolerance, $\pm 100 \mathrm{ppm}$; fragment mass tolerance, $\pm 0.1 \mathrm{Da}$; max missed cleavages, 1 ; ions score or expect cut-off, 30; max missed cleavages - 1, SwissProt database with the taxonomy restricted to
Homo sapiens (20348 sequences); fragmentation mode, HCD; significance threshold, $\mathrm{p}<0,05$.

\section{Bioinformatic analysis}

To visualize molecular interaction network for eEF1B $\beta$ we used Cytoscape 3.2.0 Program [10]. The Cytoscape 3.2.0 interaction database BIOGRID was supplemented with newly identified protein partners of eEF1B $\beta$ in nuclear fraction of the cells and analyzed by MCODE plugin which finds clusters (highly interconnected regions) in any network loaded into Cytoscape. MCODE analysis was performed on the hybrid supercomputer "SCIT-4" of the Glushkov Institute of Cybernetics (GIC) of National Academy of Sciences of Ukraine (http://icybcluster.org.ua).

Analysis of the nuclear protein partners which are co-fractionated with eEF1B $\beta$ in the course of a number of subsequent centrifugations was carried out by use of Mapofthecell program (http://www.mapofthecell.org). All protein partners identified by co-precipitation studies were tested for a possibility of their co-fractionation with eEF1B $\beta$ as described in [11].

\section{Results and Discussion}

The co-immunoprecipitation of cellular proteins with anti-EF1B $\beta$ antibodies in nuclear extract of A549 cells was used to sort out the protein partners of the elongation factor eEF1B $\beta$. Mass-spectrometric identification of the protein partners of eEF1B $\beta$ was carried out as described in Materials and Methods section. 104 proteins were identified as interacting partners of eEF1B $\beta$ in the nuclear fraction of human lung carcinoma cells. 
As these proteins obviously belong to different functional classes we attempted to classify the nuclear molecular networks which could involve eEF1B $\beta$, by using MCODE plugin in the Cytoscape 3.2.0 program [10]. This approach has been successfully used by us recently for clustering the cytoplasmic partners of eEF1B $\beta$ [12].

Surprisingly, Cytoscape 3.2.0 was not capable to reveal any functional cluster of the 104 protein partners of eEF1B $\beta$ in nucleus. At present, we are not aware of the reason behind this.

For independent estimation of the possible interactions it is important to use methodically different approach. Precise co-fractionation of the cellular proteins was recently described as an alternative way to estimate a possibility of their interaction [11]. The Mapofthecell program contains a database of the spatial proteome of cancer cells based on the study of precise subcellular localization of human proteins.
Throughout analysis of the spatial proteome of cancer cells by the Mapofthecell program for the presence of nuclear protein partners of eEF1B $\beta$, detected earlier by the co-immunoprecipitation procedure, has identified nine protein partners confirmed by both co-immunoprecipitation and co-fractionation studies (Table 1). Their characteristics are given below.

Interleukin enhancer-binding factor 2 (ILF2) is a transcription factor which control the interleukin 2 gene transcription. ILF2 forms a complex with ILF3 protein which modulates its RNA-binding properties of the latter [13]. ILF2 regulates RNA splicing and DNA damage response in multiple myeloma [14].

ILF2 functions as an oncogene, regulates epithelial-mesenchymal transition associated genes in pancreatic carcinoma cells [15], and is involved in hepatocellular carcinoma $[16,17]$. Overexpression of ILF2 in gastric

Table 1. Protein partners of eEF1Bß identified by both mass-spectrometry and precise subcellular cofractionation

\begin{tabular}{|c|c|c|c|c|c|}
\hline \multirow{2}{*}{ № } & \multirow{2}{*}{ Gene names } & \multirow{2}{*}{ Protein names } & \multicolumn{2}{|c|}{ Localization } & \multirow{2}{*}{ Association with lung cancer } \\
\hline & & & Cyto & Nucl & \\
\hline 1 & ILF2 & Interleukin enhancer-binding factor 2 & ++ & ++++ & Yes \\
\hline 2 & ILF3 & Interleukin enhancer-binding factor 3 & + & ++++ & Yes \\
\hline 3 & HNRNPU & Heterogenous nuclear ribonucleoprotein $\mathrm{U}$ & + & ++++ & Yes \\
\hline 4 & CELF1 & GUGBP Elav-like family member 1 & + & ++++ & Yes \\
\hline 5 & USP39 & Ubiquitin specific peptidase 39 & + & ++++ & Yes \\
\hline 6 & DDX6 & DEAD-Box Helicase 6( & ++ & ++ & No \\
\hline 7 & PA2G4 & $\begin{array}{l}\text { p42 isoform of Proliferation-associated } \\
\text { protein } 2 \mathrm{G} 4\end{array}$ & ++++ & ++ & No \\
\hline 8 & SPATS2L & $\begin{array}{l}\text { Spermatogenesis Associated Serine Rich } 2 \\
\text { Like protein }\end{array}$ & ++ & ++ & No \\
\hline 9 & CCNT1 & Cyclin T1 & ++ & ++++ & No \\
\hline
\end{tabular}

Intracellular localization is given according to human cell database GeneCards (http://www.genecards.org) 
cancer is associated with poor prognosis [18]. Importantly, there is a link of ILF2 with lung cancer [19].

Interleukin enhancer-binding factor 3 (ILF3) is a multifunctional protein, which is involved in RNA metabolism, including transcription, degradation, and translation. In addition, it was shown that ILF3 regulates microRNA expression [see for review 20] It interacts with nuclear export machinery [21] and is involved in viral replication [22].

ILF3 is overexpressed in lung carcinoma cells [23]. Stabilization of ILF3 protein by means of lncRNA-LET downregulation contributes to the hypoxia-induced lung cancer cell invasion [24].

Heterogenous nuclear ribonucleoprotein $U$ (HNRNPU) is involved in pre-mRNA splicing [25], takes part in DNA double-strand break (DSB) signaling and repair [26], is involved into the complex providing the c-myc mRNA stability [27].

Loss of HNRNPU causes development of a neurodevelopmental syndrome [28], HNRNPU is involved in adipose tissue biology [29].

Overexpression of miR-193a-3p leads to down regulation of HNRNPU which indicates a possibility of its involvement to non-smallcell lung carcinoma [30].

GUGBP Elav-like family member 1 (CELF1) is a RNA-binding protein which participates in mRNA targeting $[31,32]$ and degradation [33]. It is involved in energy homeostasis transition in adipose tissue [34]. Controls alternative splicing in human cells [35]. Participates in microRNA destabilization [36]. CELF1 protected cardiomyocytes from ischemia-induced injury through the promotion of angiogenesis and inhibition of apoptosis [37].
CELF1 protein functions as a central node controlling translational activation of genes driving epithelial-to-mesenchymal transition and ultimately tumor progression [38]. It promotes glioma [39] and oral squamous cell [40] carcinomas. However, non-phosphorylated at S302 CELF1 is, in fact, potent tumor-suppressor [41]. Importantly, there are multiple links of CELF1 to lung cancer [42-47].

Ubiquitin specific peptidase 39 (USP39) is a deubiquitinating enzyme without ubiquitin protease activity, which is a component of spliceosome [48]. USP39 has been implicated in the progression of several cancers [49-51]

Importantly, USP39 is overexpressed in lung cancer cells and promotes their proliferation [52]. USP39 is up-regulated in lung and colon carcinomas and its expression correlates with poor clinical outcome, so USP39-targeting strategies were suggested as the basis of new anticancer therapies [53].

DEAD-Box Helicase 6 (DDX6) functions in cytoplasmic RNA regulation. It is also found in nucleus, with unknown role [54].

DDX6 fulfils a progenitor function through two distinct pathways that include the degradation of differentiation-inducing transcripts and by promoting the translation of self-renewal and proliferation mRNAs [55]. DDX6 represses aberrant activation of interferon-stimulated genes [56]. DDX6 modulates interaction of miR-122 with the 5' untranslated region of hepatitis C virus RNA [57]. DDX6 was involved in radio- and chemo resistance in glioblastoma [58], however, the exact role of DDX6 in this case was not identified.

The short isoform, $p 42$, of Proliferationassociated protein $2 G 4$ (PA2G4) promotes cell differentiation [59]. The isoform p42 
Ebp1 functions as a potent tumor suppressor of NSCLC through interruption of Akt signaling [60]. PA2G4 P42 stabilized the interaction of SCF-type ubiquitin ligase FBXW7 with its substrates and promoted FBXW7mediated degradation of oncogenic targets, enhancing its overall tumor-suppressing function [61].

Limited information is available on SPATS2like protein (SPATS2L). It is found that SPATS2L can be targeted by microRNA1269 a, downregulation of the latter promotes the occurrence and process of hepatocellular carcinoma [62]. However, the direct link of SPATS2L to cancer was not demonstrated. Interestingly, SPATS2L mRNA is found among highly overexpressed mRNAs in systemic lupus erythematosus [63].

Cyclin $T 1$ (CCNT1) is a regulatory subunit of the CDK9/cyclin-T1 cyclin-dependent kinase complex, which promotes transcription via phosphorylation of RNA polymera- se II [64]. This complex is a target of many anti-cancer drugs [65-67] and is important for anti-viral therapy as well [68-70].

Importantly, five out from nine identified protein partners of eEF1B $\beta$ demonstrated obvious connections to lung cancer. Peculiarly, these five proteins showed quite similar localization in a cellular topology map (Fig. 1). Cyclin T1, which is a transcription factor of general significance, was also adjacent to the lung cancer-related cluster (Fig. 1). Furthermore, the eEF1B $\beta$ partners with no marked pro-oncogenic action were closely co-localized in another segment of the map (Fig. 2). Tumor suppressor PA2G4 was involved in this group as well.

Close co-localization of the proteins in cellular topology map is considered as a sign of their potential ability to be involved in the same complex in cell [11]. Subsequently, one cannot exclude that the ILF2, ILF3, HNRNPU, CELF1, USP39 proteins, or at least some of
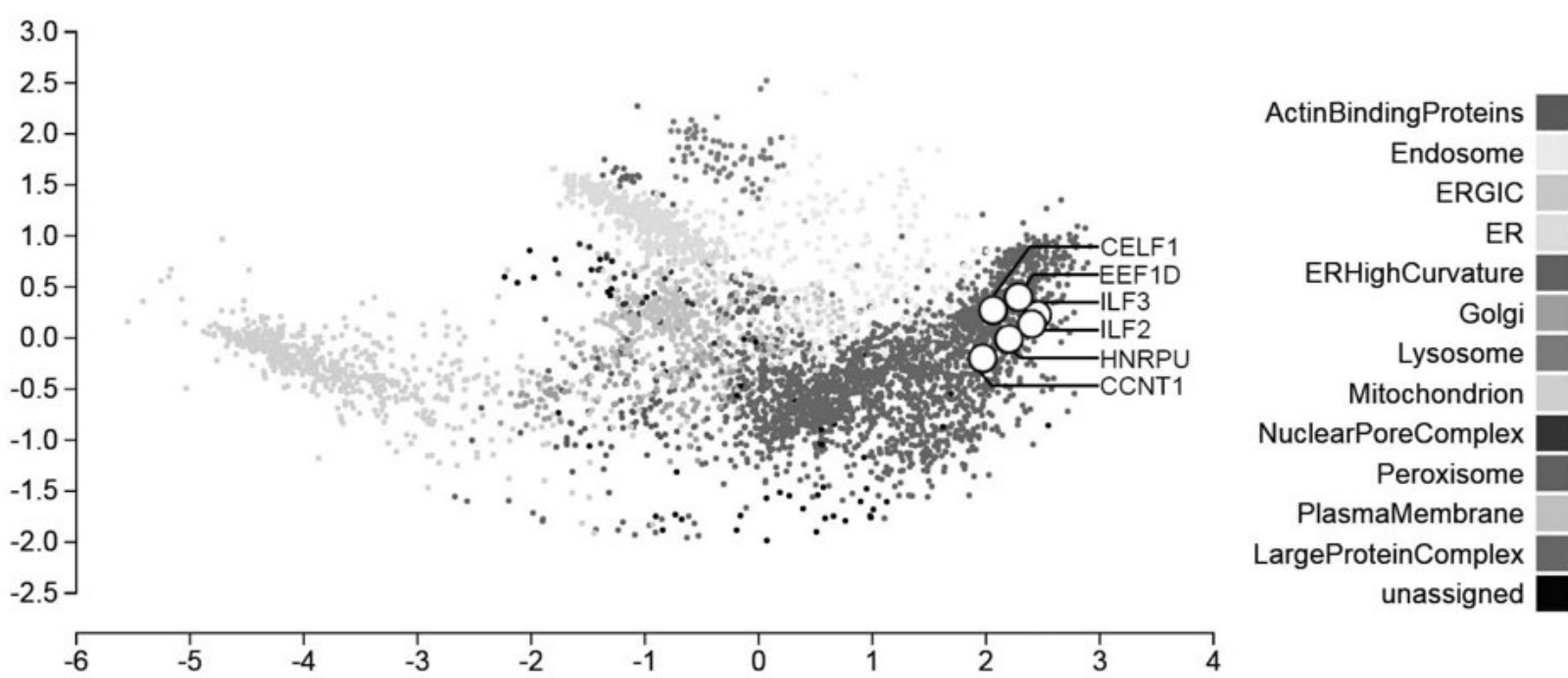

Fig. 1. Consortium of the eEF1B $\beta$ protein partners involved in human lung cancer. "Mapofthecell" database (http:// www.mapofthecell.org) (Map 5) was used. EEF1D is a gene name for eEF1B $\beta$ protein. 

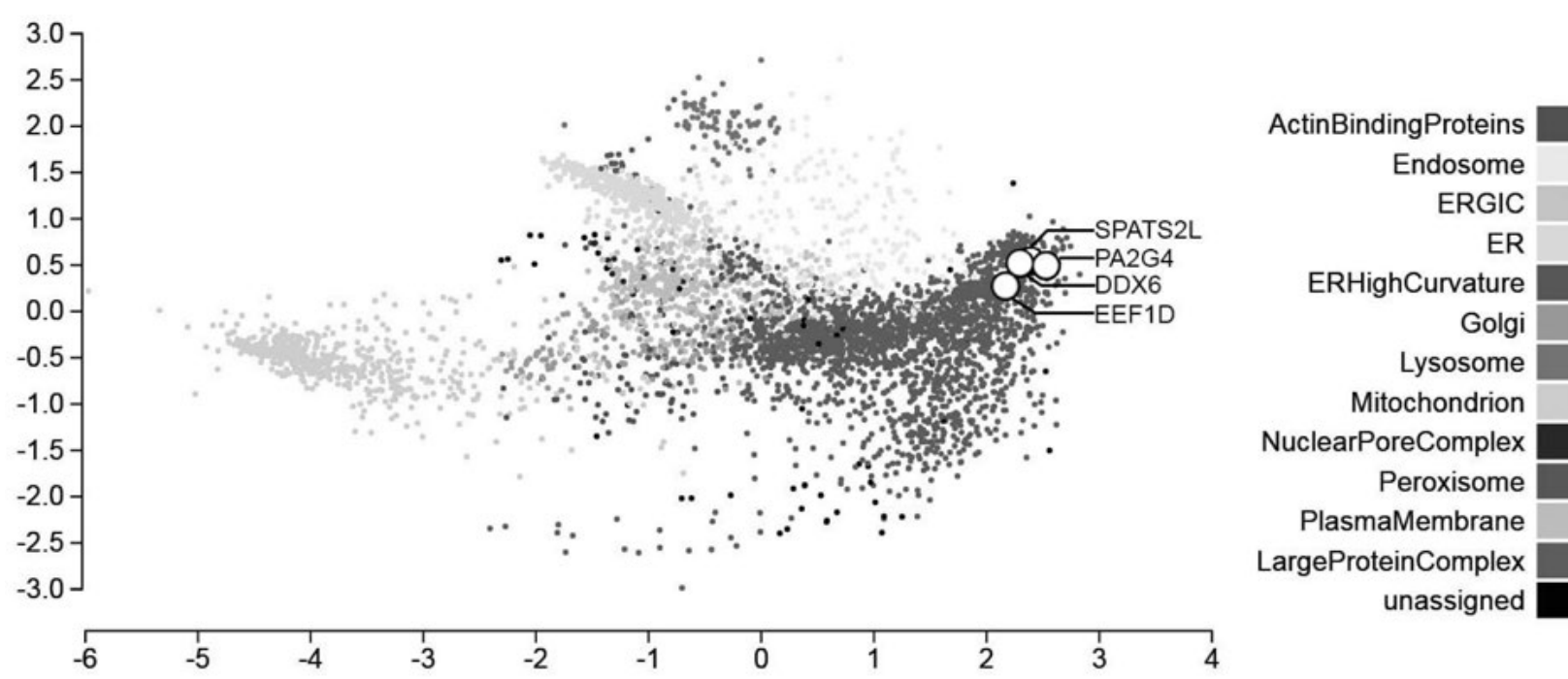

Fig. 2. Consortium of the eEF1B $\beta$ protein partners which are not reported to be involved in human lung cancer. "Mapofthecell" database (http://www.mapofthecell.org) (Map 6) was used. EEF1D is a gene name for eEF1B $\beta$ protein.

them, form a complex in the nucleus of lung cancer cells which interacts with a nucleuslocalized portion of the translation factor eEF1B $\beta$ population. Importantly, the complex of ILF2 and ILF 3 was already described [13].
Moreover, recently a complex of ILF2 and HNRNPU with long intergenic noncoding RNA was detected and shown to be important for mouse embryogenesis [71]. To our knowledge, an ability of other eEF1B $\beta$ partners to

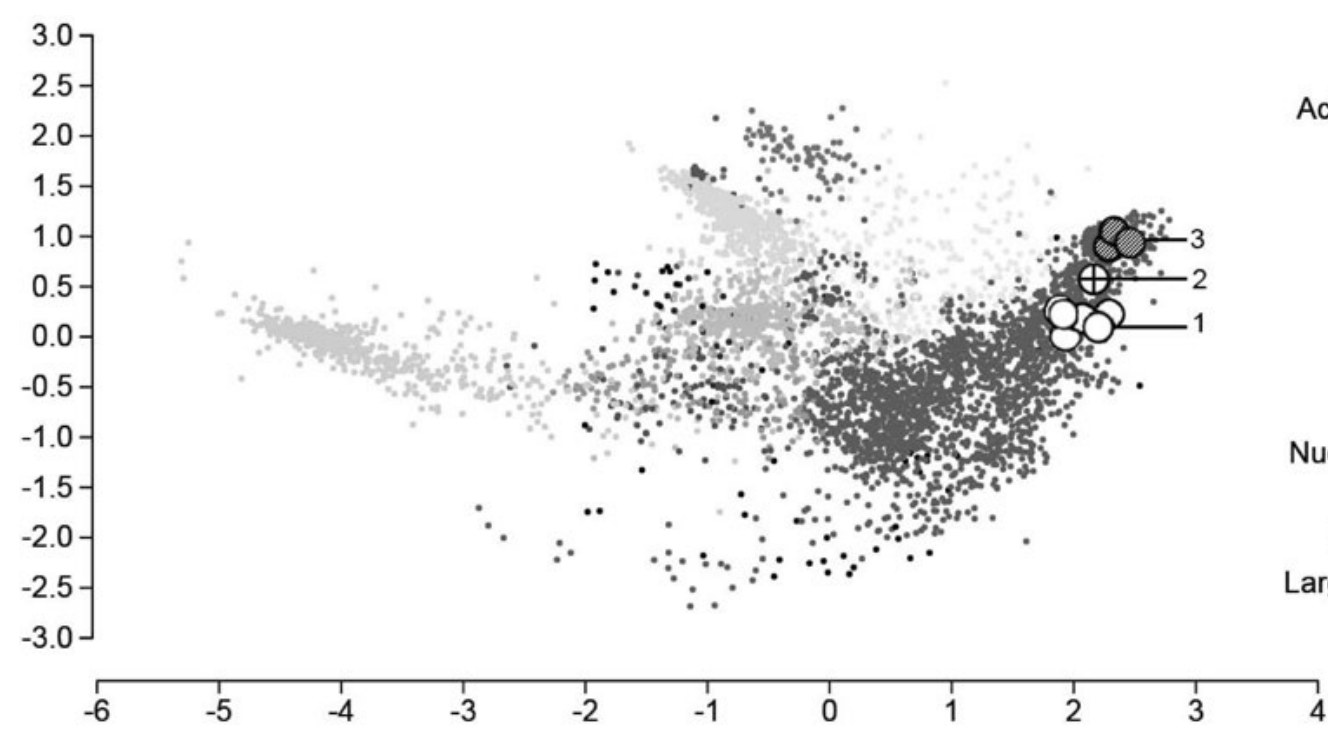

Fig. 3. Groups of pro-oncogenic (1) and neutral/tumor-suppressing (3) proteins can be spatially separated and linked by eEF1B $\beta$ (2). Map 1 of "Mapofthecell" database was used. 
interact with each other is not yet deciphered. Importantly, all these proteins show mainly nuclear localization (Table 1). On the contrary, the group of the eEF1B $\beta$ partners involving tumor-suppressor protein PA2G4 demonstrates both nuclear and cytoplasmic localization, which is valid also for eEF1B $\beta$. One may suggest that cyto-nucleo shuttling of eEF1B $\beta$ might provide as well a re-distribution of its partners between these cellular compartments. Leucine-zipper motif present in the eEF1B $\beta$ molecule [72] can be responsible for these multiple and reversible interactions.

One may suggest that a co-compartmentalization of lung cancer-related eEF1B $\beta$ partners in nucleus may facilitate cumulative oncogenic action of these proteins. This predicts novel, unforeseen before, level of complexity of regulation of cancer-related processes in human cell. The position of eEF1B $\beta$ as an intermediate link between oncogenic and tumor-suppressor moieties of its protein partners (Fig. 3) can make it an important regulatory element of a switch between normal and cancer realities of a cell. This raises a question of identification of the mechanism of the eEF1B $\beta$ release from the eEF1B complex and deciphering the role of eEF1B $\beta$ shuttling between procancer and anti-cancer communities of its protein partners.

\section{Conclusions}

104 proteins were identified as interacting partners of eEF1B $\beta$ in the nuclear fraction of human lung carcinoma cells. From this amount, 9 protein partners were found to be co-fractionated with eEF1B $\beta$ during precise cell fractionation procedures. Functional analysis of the partners has divided them on the pro-on- cogenic and neutral/anti-oncogenic moieties. ILF2, ILF3, HNRNPU, CELF1, USP39 are pro-oncogenic and, moreover, strongly coupled to lung cancer. On the contrary, the cancer relation of DDX6 and SPATS2L is not obvious while PA2G4p42 shows potent tumor-suppressing properties. We believe that the position of eEF1B $\beta$ as an intermediate link between the oncogenic and tumor-suppressor moieties of its protein partners can make it an important regulatory element and possible target of anti-cancer therapy.

\section{Acknowledgments}

This work was partially financed by the Interdisciplinary Program of Scientific research of NAS of Ukraine "Molecular and cell biotechnologies for medicine, industry and agriculture".

We thank V. Zakon and Dr. I. Groisman for their help to systematize MS data and Dr. O. Novosylna for help with preparation of figures.

\section{REFERENCES}

1. Negrutskii B, Vlasenko D, El'skaya A. From global phosphoproteomics to individual proteins: the case of translation elongation factor eEF1A. Expert Rev Proteomics. 2012;9(1):71-83.

2. Novosylna AV, Timchenko AA, Tiktopulo EI, Serdyuk IN, Negrutskii BS, El'skaya AV. Characterization of physical properties of two isoforms of translation elongation factor 1A. Biopolym Cell. 2007; 23(5):386-90.

3. Veremieva M, Khoruzhenko A, Zaicev S, Negrutskii $B$, El'skaya $A$. Unbalanced expression of the translation complex eEF1 subunits in human cardioesophageal carcinoma. Eur $J$ Clin Invest. 2011;41(3):269-76.

4. Veremieva M, Kapustian L, Khoruzhenko A, Zakharychev $V$, Negrutskii $B$, El'skaya $A$. Independent overexpression of the subunits of translation elonga- 
tion factor complex eEF1H in human lung cancer. BMC Cancer. 2014;14:913.

5. Joseph P, Lei YX, Ong TM. Up-regulation of expression of translation factors--a novel molecular mechanism for cadmium carcinogenesis. Mol Cell Biochem. 2004;255(1-2):93-101.

6. Ogawa K, Utsunomiya T, Mimori K, Tanaka Y, Tanaka F, Inoue H, Murayama S, Mori M. Clinical significance of elongation factor-1 delta mRNA expression in oesophageal carcinoma. Br J Cancer. 2004;91(2):282-6.

7. Sinha P, Kohl S, Fischer J, Hütter G, Kern M, Köttgen E, Dietel M, Lage H, Schnölzer M, Schaden$\operatorname{dorf} D$. Identification of novel proteins associated with the development of chemoresistance in malignant melanoma using two-dimensional electrophoresis. Electrophoresis. 2000;21(14):3048-57.

8. Dignam JD, Lebovitz RM, Roeder RG. Accurate transcription initiation by RNA polymerase II in a soluble extract from isolated mammalian nuclei. Nucleic Acids Res. 1983;11(5):1475-89.

9. Kang D, Gho YS, Kang C. Highly sensitive and fast protein detection with coomassie brilliant blue in sodium dodecyl sulfate-polyacrylamide gel electrophoresis. Bull Korean Chem Soc. 2002; 23(11): 1511-2.

10. Shannon P, Markiel A, Ozier O, Baliga NS, Wang JT, Ramage D, Amin N, Schwikowski B, Ideker T. Cytoscape: a software environment for integrated models of biomolecular interaction networks. Genome Res. 2003;13(11):2498-504.

11. Itzhak DN, Tyanova S, Cox J, Borner GH. Global, quantitative and dynamic mapping of protein subcellular localization. Elife. 2016;5. pii: e16950.

12. Kapustian LM, Dadlez M, Negrutskii BS. Non-canonical interactions of the $\beta$ subunit of the translation elongation complex eEF1B and analysis of their possible functional role. Biopolym Cell. 2016; 32(5):347-58.

13. Schmidt T, Knick P, Lilie H, Friedrich S, Golbik RP, Behrens $S E$. The properties of the RNA-binding protein NF90 are considerably modulated by complex formation with NF45. Biochem J. 2017;474(2):259-80.

14. Marchesini M, Ogoti Y, Fiorini E, Aktas Samur A, Nezi L, D’Anca M, Storti P, Samur MK, Ganan-
Gomez I, Fulciniti MT, Mistry N, Jiang S, Bao N, Marchica V, Neri A, Bueso-Ramos C, Wu CJ, Zhang L, Liang H, Peng X, Giuliani N, Draetta G, Clise-Dwyer K, Kantarjian H, Munshi N, Orlowski R, Garcia-Manero G, DePinho RA, Colla S. ILF2 is a regulator of RNA splicing and dna damage response in 1q21-amplified multiple myeloma. Cancer Cell. 2017;32(1):88-100.e6.

15. Bi Y, Shen W, Min M, Liu Y. MicroRNA-7 functions as a tumor-suppressor gene by regulating ILF2 in pancreatic carcinoma. Int J Mol Med. 2017;39(4): 900-6.

16. Cheng $S$, Jiang $X$, Ding $C, D u C$, Owusu-Ansah $K G$, Weng X, Hu W, Peng C, Lv Z, Tong R, Xiao H, Xie H, Zhou L, Wu J, Zheng S. Expression and critical role of interleukin enhancer binding factor 2 in hepatocellular carcinoma. Int J Mol Sci. 2016;17(8). pii: E1373.

17. Higuchi T, Todaka H, Sugiyama Y, Ono M, Tamaki N, Hatano E, Takezaki Y, Hanazaki K, Miwa T, Lai S, Morisawa K, Tsuda M, Taniguchi T, Sakamoto S. Suppression of microRNA-7 (miR-7) biogenesis by nuclear factor 90-nuclear factor 45 complex (NF90NF45) controls cell proliferation in hepatocellular carcinoma. J Biol Chem. 2016;291(40):21074-84.

18. Yin ZH, Jiang $X W$, Shi WB, Gui $Q L$, Yu DF. Expression and clinical significance of ILF2 in gastric cancer. Dis Markers. 2017;2017:4387081.

19. Ni T, Mao G, Xue Q, Liu Y, Chen B, Cui X, Lv L, Jia L, Wang Y, Ji L. Upregulated expression of ILF2 in non-small cell lung cancer is associated with tumor cell proliferation and poor prognosis. $J \mathrm{Mol}$ Histol. 2015;46(4-5):325-35.

20. Masuda K, Kuwano Y, Nishida K, Rokutan K, Imoto $I$. NF90 in posttranscriptional gene regulation and microRNA biogenesis. Int J Mol Sci. 2013;14(8): 17111-21.

21. Pei Y, Zhu P, Dang Y, Wu J, Yang X, Wan B, Liu JO, Yi $Q$, Yu $L$. Nuclear export of NF90 to stabilize IL-2 mRNA is mediated by AKT-dependent phosphorylation at Ser647 in response to CD28 costimulation. J Immunol. 2008;180(1):222-9.

22. Li X, Liu $C X$, Xue $W$, Zhang $Y$, Jiang $S$, Yin $Q F$, Wei J, Yao $R W$, Yang L, Chen LL. Coordinated circRNA Biogenesis and Function with NF90/ 
NF110 in Viral Infection. Mol Cell. 2017;67(2):214227.e7.

23. Korrodi-Gregório L, Soto-Cerrato V, Vitorino $R$, Fardilha M, Pérez-Tomás R. From Proteomic Analysis to Potential Therapeutic Targets: Functional Profile of Two Lung Cancer Cell Lines, A549 and SW900, Widely Studied in Pre-Clinical Research. PLoS One. 2016;11(11):e0165973.

24. Yang F, Huo XS, Yuan SX, Zhang L, Zhou WP, Wang F, Sun SH. Repression of the long noncoding RNA-LET by histone deacetylase 3 contributes to hypoxia-mediated metastasis. Mol Cell. 2013;49(6): 1083-96.

25. Ye J, Beetz N, O'Keeffe S, Tapia JC, Macpherson L, Chen WV, Bassel-Duby R, Olson EN, Maniatis $T$. hnRNP $\mathrm{U}$ protein is required for normal pre-mRNA splicing and postnatal heart development and function. Proc Natl Acad Sci U S A. 2015;112(23):E3020-9.

26. Polo SE, Blackford AN, Chapman JR, Baskcomb L, Gravel S, Rusch A, Thomas A, Blundred R, Smith P, Kzhyshkowska J, Dobner T, Taylor AM, Turnell AS, Stewart GS, Grand RJ, Jackson SP. Regulation of DNA-end resection by hnRNPU-like proteins promotes DNA double-strand break signaling and repair. Mol Cell. 2012;45(4):505-16.

27. Weidensdorfer D, Stöhr N, Baude A, Lederer M, Köhn M, Schierhorn A, Buchmeier S, Wahle E, Hüttelmaier $S$. Control of c-myc mRNA stability by IGF2BP1-associated cytoplasmic RNPs. RNA. 2009; 15(1):104-15.

28. Yates TM, Vasudevan PC, Chandler KE, Donnelly DE, Stark Z, Sadedin S, Willoughby J; Broad Center for Mendelian Genomics; DDD study, Balasubramanian $M$. De novo mutations in HNRNPU result in a neurodevelopmental syndrome. Am J Med Genet A. 2017;173(11):3003-12.

29. Li S, Mi L, Yu L, Yu Q, Liu T, Wang GX, Zhao XY, $W u J$, Lin JD. Zbtb7b engages the long noncoding RNA Blnc1 to drive brown and beige fat development and thermogenesis. Proc Natl Acad Sci U S A. 2017;114(34):E7111-E7120.

30. Deng W, Yan M, Yu T, Ge H, Lin H, Li J, Liu Y, Geng $Q$, Zhu M, Liu L, He X, Yao M. Quantitative proteomic analysis of the metastasis-inhibitory mechanism of miR-193a-3p in non-small cell lung cancer. Cell Physiol Biochem. 2015;35(5):1677-88.

31. Yu TX, Gu BL, Yan JK, Zhu J, Yan WH, Chen J, Qian LX, Cai W. CUGBP1 and HuR regulate E-cadherin translation by altering recruitment of E-cadherin mRNA to processing bodies and modulate epithelial barrier function. Am J Physiol Cell Physiol. 2016;310(1):C54-65.

32. Bohjanen PR, Moua ML, Guo L, Taye A, VlasovaSt Louis IA. Altered CELF1 binding to target transcripts in malignant $\mathrm{T}$ cells. RNA. 2015;21(10): 1757-69.

33. Chang KT, Cheng CF, King PC, Liu SY, Wang GS. CELF1 Mediates Connexin 43 mRNA Degradation in Dilated Cardiomyopathy. Circ Res. 2017;121(10): 1140-52.

34. Bai Z, Chai XR, Yoon MJ, Kim HJ, Lo KA, Zhang ZC, $X u$ D, Siang DTC, Walet ACE, Xu SH, Chia SY, Chen P, Yang H, Ghosh S, Sun L. Dynamic transcriptome changes during adipose tissue energy expenditure reveal critical roles for long noncoding RNA regulators. PLoS Biol. 2017;15(8):e2002176. 35. Xia H, Chen D, Wu Q, Wu G, Zhou Y, Zhang Y, Zhang $L$. CELF1 preferentially binds to exon-intron boundary and regulates alternative splicing in HeLa cells. Biochim Biophys Acta. 2017;1860(9):911-21.

36. Katoh T, Hojo H, Suzuki T. Destabilization of microRNAs in human cells by 3' deadenylation mediated by PARN and CUGBP1. Nucleic Acids Res. 2015;43(15):7521-34.

37. Gu L, Wang H, Wang J, Guo Y, Tang Y, Mao Y, Chen L, Lou H, Ji G. Reconstitution of HuR-inhibited CUGBP1 expression protects cardiomyocytes from acute myocardial infarction-induced injury. antioxid redox signal. 2017;27(14):1013-26.

38. Chaudhury A, Cheema S, Fachini JM, Kongchan N, Lu G, Simon LM, Wang T, Mao S, Rosen DG, Ittmann MM, Hilsenbeck SG, Shaw CA, Neilson JR. CELF1 is a central node in post-transcriptional regulatory programmes underlying EMT. Nat Commun. 2016;7:13362.

39. Xia L, Sun C, Li Q, Feng F, Qiao E, Jiang L, Wu B, Ge M. CELF1 is up-regulated in glioma and promotes glioma cell proliferation by suppression of CDKN1B. Int J Biol Sci. 2015;11(11):1314-24. 
40. House RP, Talwar S, Hazard ES, Hill EG, Palanisa$m y V$. RNA-binding protein CELF1 promotes tumor growth and alters gene expression in oral squamous cell carcinoma. Oncotarget. 2015;6(41):43620-34.

41. Lewis K, Valanejad L, Cast A, Wright M, Wei C, Iakova P, Stock L, Karns R, Timchenko L, Timchenko $N$. RNA binding protein cugbp1 inhibits liver cancer in a phosphorylation-dependent manner. Mol Cell Biol. 2017;37(16). pii: e00128-17.

42. Jiao W, Zhao J, Wang M, Wang Y, Luo Y, Zhao Y, Tang $D$, Shen $Y$. CUG-binding protein 1 (CUGBP1) expression and prognosis of non-small cell lung cancer. Clin Transl Oncol. 2013;15(10):789-95.

43. Wu LN, Xue YJ, Zhang LJ, Ma XM, Chen JF. SiRNA mediated knockdown of CELF1 gene suppressed the proliferation of human lung cancer cells. Cancer Cell Int. 2013;13(1):115.

44. Gao C, Yu Z, Liu S, Xin H, Li X. Overexpression of CUGBP1 is associated with the progression of nonsmall cell lung cancer. Tumour Biol. 2015;36(6): 4583-9.

45. Zhao J, Zhao Y, Xuan Y, Jiao W, Qiu T, Wang Z, Luo $Y$. Prognostic impact of CUG-binding protein 1 expression and vascular invasion after radical surgery for stage IB nonsmall cell lung cancer. Indian J Cancer. 2015;52 Suppl 2:e125-9.

46. Lu H, Yu Z, Liu S, Cui L, Chen X, Yao R. CUGBP1 promotes cell proliferation and suppresses apoptosis via down-regulating $\mathrm{C} / \mathrm{EBP} \alpha$ in human non-small cell lung cancers. Med Oncol. 2015;32(3):82.

47. Lin PC, Huang HD, Chang CC, Chang YS, Yen JC, Lee CC, Chang WH, Liu TC, Chang JG. Long noncoding RNA TUG1 is downregulated in non-small cell lung cancer and can regulate CELF1 on binding to PRC2. BMC Cancer. 2016;16:583.

48. Hadjivassiliou H, Rosenberg OS, Guthrie C. The crystal structure of S. cerevisiae Sad1, a catalytically inactive deubiquitinase that is broadly required for pre-mRNA splicing. RNA. 2014;20(5):656-69.

49. An Y, Yang S, Guo K, Ma B, Wang Y. Reduced USP39 expression inhibits malignant proliferation of medullary thyroid carcinoma in vitro. World $J$ Surg Oncol. 2015;13(1):255.

50. Zhao Y, Zhang B, Lei Y, Sun J, Zhang Y, Yang S, Zhang $X$. Knockdown of USP39 induces cell cycle arrest and apoptosis in melanoma. Tumour Biol. 2016;37(10):13167-76.

51. Yuan X, Sun X, Shi X, Jiang C, Yu D, Zhang $W$, Guan W, Zhou J, Wu Y, Qiu Y, Ding Y. USP39 promotes the growth of human hepatocellular carcinoma in vitro and in vivo. Oncol Rep. 2015;34(2): 823-32.

52. Lin Z, Xiong L, Lin $Q$. Ubiquitin-specific protease 39 is overexpressed in human lung cancer and promotes tumor cell proliferation in vitro. Mol Cell Biochem. 2016;422(1-2):97-107.

53. Fraile JM, Manchado E, Lujambio A, Quesada V, Campos-Iglesias D, Webb TR, Lowe SW, LópezOtín C, Freije JM. USP39 deubiquitinase is essential for KRAS oncogene-driven cancer. J Biol Chem. 2017;292(10):4164-75.

54. Huang JH, Ku WC, Chen YC, Chang YL, Chu CY. Dual mechanisms regulate the nucleocytoplasmic localization of human DDX6. Sci Rep. 2017;7:42853.

55. Wang Y, Arribas-Layton M, Chen Y, Lykke-Andersen J, Sen GL. DDX6 orchestrates mammalian progenitor function through the mRNA degradation and translation pathways. Mol Cell. 2015;60(1):118-30.

56. Lumb JH, Li Q, Popov LM, Ding S, Keith MT, Merrill BD, Greenberg $H B$, Li JB, Carette JE. DDX6 represses aberrant activation of interferon-stimulated genes. Cell Rep. 2017;20(4):819-31.

57. Biegel JM, Henderson E, Cox EM, Bonenfant G, Netzband R, Kahn S, Eager R, Pager CT. Cellular DEAD-box RNA helicase DDX6 modulates interaction of miR-122 with the 5' untranslated region of hepatitis C virus RNA. Virology. 2017;507:231-241.

58. Cho YJ, Kang W, Kim SH, Sa JK, Kim N, Paddison PJ, Kim M, Joo KM, Hwang YI, Nam DH. Involvement of DDX6 gene in radio- and chemoresistance in glioblastoma. Int J Oncol. 2016;48(3): 1053-62.

59. Liu Z, Ahn JY, Liu X, Ye K. Ebp1 isoforms distinctively regulate cell survival and differentiation. Proc Natl Acad Sci U S A. 2006;103(29):10917-22.

60. Ko HR, Nguyen TL, Kim CK, Park Y, Lee KH, $A h n J Y$. P42 Ebp1 functions as a tumor suppressor in non-small cell lung cancer. BMB Rep. 2015;48(3): 159-65.

61. Wang Y, Zhang P, Wang Y, Zhan P, Liu C, Mao JH, Wei $G$. Distinct Interactions of EBP1 Isoforms with 
FBXW7 Elicits Different Functions in Cancer. Cancer Res. 2017;77(8):1983-96.

62. Min P, Li W, Zeng D, Ma Y, Xu D, Zheng $W$, Tang F, Chen J, Shi J, Hu H, Wang J, Yang D, Liu J, Zhang J, Zhang $M$. A single nucleotide variant in microRNA1269a promotes the occurrence and process of hepatocellular carcinoma by targeting to oncogenes SPATS2L and LRP6. Bull Cancer. 2017;104(4):311-20.

63. Fan H, Zhao G, Ren D, Liu F, Dong G, Hou Y. Gender differences of $B$ cell signature related to estrogen-induced IFI44L/BAFF in systemic lupus erythematosus. Immunol Lett. 2017;181:71-8.

64. Franco LC, Morales F, Boffo S, Giordano A. CDK9: A key player in cancer and other diseases. $J$ Cell Biochem. 2017.

65. Zhang Y, Zhou L, Leng Y, Dai Y, Orlowski RZ, Grant $S$. Positive transcription elongation factor $\mathrm{b}$ $(\mathrm{P}-\mathrm{TEFb})$ is a therapeutic target in human multiple myeloma. Oncotarget. 2017;8(35):59476-91.

66. Li Y, Guo Q, Zhang C, Huang Z, Wang T, Wang X, Wang $X, X u$ G, Liu Y, Yang S, Fan Y, Xiang R. Discovery of a highly potent, selective and novel CDK9 inhibitor as an anticancer drug candidate. Bioorg Med Chem Lett. 2017;27(15):3231-7.

67. Narita T, Ishida T, Ito A, Masaki A, Kinoshita S, Suzuki S, Takino H, Yoshida T, Ri M, Kusumoto S, Komatsu H, Imada K, Tanaka Y, Takaori-Kondo A, Inagaki H, Scholz A, Lienau P, Kuroda T, Ueda R, Iida $S$. Cyclin-dependent kinase 9 is a novel specific molecular target in adult T-cell leukemia/lymphoma. Blood. 2017;130(9):1114-24.

68. Mbonye U, Karn J. The molecular basis for human immunodeficiency virus latency. Annu Rev Virol. 2017;4(1):261-85.

69. Zhao Z, Tang KW, Muylaert I, Samuelsson T, Elias P. CDK9 and SPT5 proteins are specifically required for expression of herpes simplex virus 1 replicationdependent late genes. $J$ Biol Chem. 2017;292(37): 15489-500.

70. Francisco JC, Dai Q, Luo Z, Wang Y, Chong RH, Tan YJ, Xie W, Lee GH, Lin C. Transcriptional Elongation Control of Hepatitis B Virus Covalently Closed Circular DNA Transcription by Super Elongation Complex and BRD4. Mol Cell Biol. 2017;37(19). pii: e00040-17.
71. Wang J, Li X, Wang L, Li J, Zhao Y, Bou G, Li Y, Jiao G, Shen X, Wei R, Liu S, Xie B, Lei L, Li W, Zhou $Q$, Liu $Z$. A novel long intergenic noncoding RNA indispensable for the cleavage of mouse twocell embryos. EMBO Rep. 2016;17(10):1452-70.

72. Bondarchuk TV, Shalak VF, Negrutskii BS, El'skaya $A V$. Leucine-zipper motif is responsible for self-association of translation elongation factor $1 \mathrm{~B} \beta$. Biopolym Cell. 2016;32(1):9-20.

\section{Білки-партнери субодиниці еЕF1Вß комплексу елонгації трансляції еЕF1В в ядерній фракції клітин карциноми легені людини}

Л. М. Капустян, М. Дадлез, Б. С. Негруцький

Мета. Виявити нових білків-партнерів фактора трансляції еEF1B $\beta$ в ядрі клітин карциноми легені. Методи. Білки-партнери еEF1B $\beta$, отримані з ядерного екстракту клітин А549 методом ко-імунопреципітації (со-IP), були ідентифіковані за допомогою высокоефективної рідинної хроматографії з тандемною мас-спектрометрією (LC-MS/MS). Подальше підтвердження білківпартнерів проводили із використанням опублікованих даних глобального, кількісного і динамічного картування субклітинної локалізації білків за допомогою програми Mapofthecell. Результати. 104 білки, які взаємодіють із еEF1B $\beta$ в ядерній фракції клітин карциноми легені А549 були ідентифіковані мас-спектрометрією. Проміж цих білків, 9 партнерів еEF1B $\beta$ були підтверджені даними із прецизійного субклітинного фракціонування. За допомогою функціонального аналізу ці білки-партнери можуть бути поділені на проонкогенну і нейтральну/анти-онкогенну групи. Передбачено, що ці групи можуть бути просторово розділені в ракових клітинах людини. Висновки. Запропоновано, що еEF1B $\beta$ може бути проміжною ланкою між онкогенною і нейтральною/пухлиносупресорною групами партнерів цього білка в ядрі ракових клітин. Розшифрування можливої ролі залучення еEF1B $\beta$ до про-ракової або анти-раковими спільнот білкових партнерів цього білку може бути предметом подальших досліджень.

К л юч о в і с л о в а: eEF1B $\beta$, білок-білкові взаємодії, клітини A549, ILF2, ILF3, HNRNPU, CELF1, DDX6, CCNT1, PA2G4, SPATS2L, USP39. 


\section{Белки-партнеры субъединицы еEF1Bß комплекса елонгации трансляции еEF1B в ядерной фракции клеток карциномы легкого}

\author{
Л. Н. Капустян, М. Дадлез, Б. С. Негруцкий
}

Цель. Выявление новых белков-партнеров фактора трансляции еEF1B $\beta$ в ядре клеток карциномы легкого.

Методы. Белки-партнёры eEF1B $\beta$, полученные из ядерного экстракта клеток А549 методом ко-иммунопреципитации (со-IP), были идентифицированы с помощью высокоэффективной жидкостной хроматографии с тандемной масс-спектрометрией (LC-MS/MS). Дальнейшее подтверждение белков-партеров проводили с использованием опубликованных ранее данных глобального, количественного ы динамичного картирования субклеточной локализации белков с помощью программы «Mapofthecell». Результаты. Методом масс-спектрометрии было идентифицировано 104 белка, взаимодействующих с еEF1B $\beta$ в ядре клеток A549. Из этих белков, 9 партнеров еЕF1В $\beta$ были под- тверждены данными, полученными при подробном субклеточном фракционировании. С помощью функционального анализа эти белки-партнеры можно разделить на про-онкогенную і нейтральную/анти-онкогенную группы. Предсказано, что эти группы могут быть разделены в пространстве в раковых клетках человека. Выводы. Выдвинуто предположение, что eEF1B $\beta$ может быть промежуточным звеном между онкогенной и нейтральной/опухоле-супрессорной группами его партнеров в ядре раковых клеток. Расшифровка возможной роли вовлечения еEF $1 \mathrm{~B} \beta$ в про-раковую или анти-раковую группы его белковых партнеров может быть предметом дальнейших исследований.

К л юч е в ы е с л о в а: еEF1B $\beta$, белок-белковые взаимодействия, клетки A549, ILF2, ILF3, HNRNPU, CELF1, DDX6, CCNT1, PA2G4, SPATS2L, USP39.

Received 23.05.2017 